\title{
Tobacco and e-cigarette shops awarded 'essential business' labels in France during COVID-19
}

\author{
Alain Braillon ${ }^{1}$
}

\section{Dear Editor,}

Egbe and Ngobese ${ }^{1}$ reported that South Africa and India banned the sale of tobacco products during lockdown periods against COVID-19. Vázquez and Redolar-Ripoll ${ }^{2}$ also previously called for strengthening population-based cessation support via: public campaigns, quitlines and nicotine replacement therapy availability. In contrast, in the US, Lang and Yakhkind ${ }^{3}$ used telehealth to scale up the tobacco cessation program in a military setting.

The inertia or lack of comprehensive measures against tobacco use during the COVID-19 pandemic is a concern as: a) the crisis not only has exacerbated risk factors for the initiation, worsening and relapse of addictive disorders but also seriously limited access to treatments; b) there has been accumulating robust evidence showing smoking worsens the progression and outcomes of viral or bacterial lung infections. Accordingly, the COVID-19 pandemic should have been a great lever for increasing motivation to quit. The state of affairs is similar for e-cigarettes, which may cause lung inflammation and increase susceptibility to pulmonary viral and bacterial infections ${ }^{4-6}$.

Only France had a comprehensive policy on tobacco during the pandemic, being among the first countries that implemented a severe lockdown, with the government issuing various levels of restrictions on non-essential activities and businesses. The Ministry of Health issued a legal decree ${ }^{7}$ explicitly allowing tobacco shops and e-cigarette shops to remain open, adding them to a detailed list of businesses previously allowed to operate on 14 March and ranking them just after 'food retail trade on stalls and markets'. The latter were forbidden to operate on 23 March by the Prime Minister. On 23 April, the Ministry of Health suspended online sales of nicotine replacement therapy and restricted delivery by pharmacies to one month's therapy ${ }^{8}$; while in parallel, the European ban on menthol cigarettes, which was to be enforced on 20 May 2020, was postponed to 31 July 2020.

In France, daily smoking prevalence was $24 \%$ in 2019, without significant changes from 2018. In light of the COVID-19 pandemic, could the government increase its revenue from tobacco taxes, which are equivalent to one-fourth of the revenue from income tax, in order to better face the COVID-19 induced economic crisis?

\section{REFERENCES}

1. Egbe CO, Ngobese SP. COVID-19 lockdown and the tobacco product ban in South Africa. Tob Induc Dis. 2020;18(May). doi:10.18332/tid/120938

2. Vázquez JC, Redolar-Ripoll D. COVID-19 outbreak impact in Spain: A role for tobacco smoking? Tob Induc Dis. 2020;18(April). doi:10.18332/tid/120005

\section{AFFILIATION \\ 1 Former senior consultant \\ CORRESPONDENCE TO \\ Alain Braillon. 27, rue Voiture, 80000 Amiens, France. E-mail: braillon.alain@gmail.com ORCID ID: https://orcid. org/0000-0001-5735-9530 \\ KEYWORDS \\ COVID-19, e-cigarettes, tobacco, public health}

Received: 5 July 2020 Accepted: 29 October 2020 
3. Lang AE, Yakhkind A. Coronavirus Disease 2019 and Smoking: How and Why We Implemented a Tobacco Treatment Campaign. Chest. 2020;158(4). doi:10.1016/j.chest.2020.06.013

4. Wu Q, Jiang D, Minor M, Chu HW. Electronic cigarette liquid increases inflammation and virus infection in primary human airway epithelial cells. PLoS One. 2014;9(9):e108342. doi:10.1371/journal.pone.0108342

5. Clapp PW, Pawlak EA, Lackey JT, et al. Flavored e-cigarette liquids and cinnamaldehyde impair respiratory innate immune cell function. Am J Physiol Lung Cell Mol Physiol. 2017;313(2):L278-L292. doi:10.1152/ajplung.00452.2016

6. Reidel B, Radicioni G, Clapp PW, et al. E-Cigarette Use Causes a Unique Innate Immune Response in the Lung, Involving Increased Neutrophilic Activation and Altered Mucin Secretion. Am J Respir Crit Care Med. 2018;197(4):492-501. doi:10.1164/rccm.201708-15900C

7. Véran O. Arrêté du 17 mars 2020 complétant l'arrêté du 14 mars 2020 portant diverses mesures relatives à la lutte contre la propagation du virus covid-19 [Arrived on March 17, 2020 supplementing the order of March 14, 2020 carrying various measures relating to the fight against the spread of the Covid-19 virus.] Journal Officiel de la République Française. March 18, 2020. NOR : SSAZ2007919A. https://www.legifrance.gouv.fr/download/pdf?id=_OM0aowJhCyfJwlpPPeetYiF3mTkUVDd1KHOMS6u0s=. Accessed July 5, 2020.

8. Véran O. Arrêté du 23 avril 2020 complétant l'arrêté du 23 mars 2020 prescrivant les mesures d'organisation et de fonctionnement du système de santé nécessaires pour faire face à l'épidémie de covid-19 dans le cadre de l'état d'urgence sanitaire [Arrived on April 23, 2020 supplementing the order of March 23, 2020 prescribing the measures for the organization and functioning of the health system necessary to deal with the epidemic of covid-19 in the context of the state of health emergency.] Journal Officiel de la République Française. April 24, 2020. NOR: SSAZ2010368A. https://www. legifrance.gouv.fr/download/pdf?id=xfDudZ8EYUNCeDsJN905CK7iCYE7xZ38nhmp7ihfx2M=. Accessed July 5, 2020. 